\title{
Energizing Activism: Motivating Activism within EdD Programs
}

\author{
Yasha Jones Becton \\ University of South Carolina \\ yyjones@mailbox.sc.edu \\ Rhonda Jeffries \\ University of South Carolina \\ rjeffries@sc.edu
}

\begin{abstract}
Do I believe in activism even in these dark days? Yes. Absolutely. I teach because I believe with all my being that teaching is the most powerful form of activism human beings have ever conceived. But we mustn't teach merely for our own fulfillment. We teach to serve. It is not about me or you. It is not about us and them. We are partners, and we can help. It can be helped. We should help. (Burns, 2020, p. 49)
\end{abstract}

In a time when easy solutions are pervasive and the demand for answers to critical questions seems unrelenting, educators are often uniquely positioned to provide context for the shifts and the changes that are needed in our society. When we think about those who serve in graduate programs, particularly Doctor of Education degree programs, there perhaps exists an even greater opportunity to motivate and inspire others to become the transformation desperately needed in our schools and in our communities. While careful observation would reveal that there are numerous natural links between academic work and activism that can be exercised, oftentimes, they remain underdeveloped in higher education (Rose, 2017).

This dichotomy exists for several reasons. One reason is that embracing or pursuing activism is not for the faint of heart. It requires a degree of grit and commitment to outcomes that may or may not fully manifest despite the concerted effort. Researchers in a related study denoted that there exists:

\begin{abstract}
an ongoing threat to the commitment to urban education, equity, and social justice within current trends in public education, yet again, there is much critical hope for awareness, advocacy, action and application to transform public education in an action that embraces equity, social justice, and culture. (Hutchison \& White, 2020, p.148)
\end{abstract}

Hence, the hope for a transformative future must outweigh any present challenges, hurdles or hindrances.

Another challenge in connecting the academic work with activism involves the fact that although activism denotes "activity" it also requires deep inner reflection and critical thinking. There is a dire need to think, and think quite carefully, before acting. Ollis (2015) posited that the pedagogy of activism is critically cognitive and expressed in a practice that is intrinsically social. As educators we are challenged to spark a level of reflection and critical thinking that serves as a catalyst for moving beyond thinking, to ensure that students serve as agents of change. This level of reflection and critical thinking acts as the flame for igniting the type and level of learning that needs to take place. "When students care about something, they are on fire to learn. Anatomically, when intensely focused, cells in the brain impact other cells, making connections faster, memory retrieval quicker, and shielding out extraneous stimuli easier" (Rose, 2017, p.73).

New articles in this journal are licensed under a Creative Commons Attribution 4.0 United States License. Program and is cosponsored by the University of Pittsburgh Press.
As part of the 2019 Carnegie Project on the Education Doctorate (CPED) October convening, the University of South Carolina Curriculum Studies program wanted to gain a more in depth understanding of how the more than 100 participants conceptualized or created a platform for the emergence of an activist. One such program in the consortium posited that the "CPED-influenced EdD prepares leaders who can construct and apply knowledge to make a positive difference in the lives of individuals, families, organizations, and communities" (Lewis, et al., 2020, p. 3). Our overarching question was how is this all-important work accomplished? To answer this question, we turned to those EdD programs that were doing the work.

What emerged from our research was a "Framework for the Emerging EdD Activist". The framework consisted of four themes related to an EdD Activist. The four themes were Coalition Builder, Vocal Risktaker, Visionary Leader and Social Justice Champion (Becton et al., 2020). These four themes were utilized to offer EdD programs the option of viewing the four emerging themes as four distinct areas of specialization that each student could pursue or four distinct areas of specialization that each student should embody. In addition to the choice between the single or multi-profile model, programs were also provided with a list of 12 comprehensive considerations that demonstrated several key areas that programs could pinpoint as necessary areas of support for EdD programs with an embedded goal of activism (Becton et al., 2020). Lastly, programs were provided with targeted outcomes and potential quality indicators to provide an on-going means of assessment and program evaluation.

To culminate our focus on the EdD Activist, part two of this special themed issue is aptly entitled, "Energizing activism: Motivating activism within EdD programs". As outlined above, in the first edition of the journal, we explored the topic of activism and offered a plausible framework for the emerging EdD Activist based on the feedback from the colleges and universities that participated in the 2019 CPED Convening. As we delved deeper into this discussion, we explored how the goal of activism is realized in various CPED-influenced programs across the nation.

To embark upon this journey, we enlisted the assistance of several programs within the CPED consortium. Our colleagues from the University of South Carolina, Bridget Miller, Christopher 
Bogiages, Jan Yow and Christine Lotter, utilized the framework developed and published in part one of the special edition to examine their newly formed STEM EdD doctoral degree program against the 12 considerations outlined in the forementioned framework. The article entitled, "Embedding activism in a STEM EdD program" offers a comprehensive explanation of how the program leaders designed a STEM EdD program that merged theory, research, and practice while positioning students to grasp their fundamental responsibility as it relates directly to social justice and activism.

Other articles in this issue focus our attention on the challenging topic of change. Antoinette Ryan and Sheldon Watson of Central Connecticut State University shared an article entitled "Transforming an EdD program in the crucible of systems change". Their study involved a thorough longitudinal analysis of dissertations in order to evaluate these studies in light of the stated principles of the program. Their research sets the stage for further opportunity for the transformation of the EdD program. Continuing our discussion regarding change, Aubrey Statti and Kelly Torres of The Chicago School of Professional Psychology explored their Doctor of Education degree program in Educational Psychology and Technology. This article examined how the EPT program provides students with the opportunity to become agents of change. The authors further examined how active learning strategies such as program residencies and peer mentorship are utilized to ensure that students are empowered to serve as advocates and understand the importance of taking action upon completion of the program. A third article demonstrates how East Carolina University's EdD program, the redesigned ECU International EdD program, empowers educational leaders from around the globe to confront equity challenges that exist within their local communities. The authors further explored how Participatory Action Research (PAR) is utilized as the primary mechanism in addressing the various equity challenges that emerge.

In "Listening to and crafting stories: Cultivating activism in online doctoral students" authors Carey Borkoski and Brianne Roos expounded on how John Hopkins University's online EdD program ensures that their students become scholar-practitioners as activists. The authors delved into the importance of compelling storytelling and the need for students to be able to effectively articulate their problems of practice while using deficit-free language. Utilizing a similar value or asset-based perspective, Joy Howard and Timberly Baker of the University of Southern Indiana drew from a Critical Race Praxis framework to support students in community-based participatory action research (CPAR). In their article entitled, "Activating activism within the EdD: Connecting DiP research and the community", the authors explored the nuances and challenges in developing and sustaining university-community partnerships to ensure the practical application and involvement of scholarship within the community. Our journey was further enlightened by the article entitled, "EdD Graduate Perspectives: Uplifting our own voices" by Staci Martin (Portland State University), Kara Gournaris (Western Oregon University), Zafreen Jaffery (Behavioral Science Research Institute), Lisa Hatfield (Oregon Health Sciences University), Su-Jin Jung (Portland State University), Li Xang (Western Michigan University), Ingrid Anderson and Micki Caskey (Portland State University). This article highlighted voices of EdD scholar-practitioners who were students of color and representatives of other marginalized student groups. Creating a platform where students stand as exemplars, the authors provided insight into the lived experiences and undeniable victories of underrepresented students.

Our journey ended with an essay entitled, "Creating a culture of activism in the education doctorate". In this article, Christine McClure challenged us with the deeper and harder questions related to what it will take to demonstrate an energized commitment to activism. One thing we know for sure is that it will take collective and sustained motivation to reach these worthwhile goals.

\section{REFERENCES}

Becton, Y., Bogiages, B., D’Amico, L., Lilly, T., Currin, E., Jeffries, R., \& Tamim, S. (2020). An emerging framework for the EdD activist, Impacting Education Journal, 5(2), 43-54.

Burns, L. D. (2020). The trouble with social justice education: Teacher identity, orthodoxy, and activism in distressed times. Curriculum \& Teaching Dialogue, 22 (1/2), 37-51.

Hutchison, L. \& White, C. (2020). Integrating culturally responsive and social justice pedagogy: A case study of an online doctorate of education degree program for instructional and professional leadership. Journal of Higher Education Theory \& Practice, 20 (2), 143-150.

Lewis, T., Puckett, H. \& Ringler, M. (2020). Changing the mindset from practitioner to scholarly practitioner: Admission through the first two semesters of an EdD program. International Journal of Education Leadership Preparation, 14(1), 1-16.

Ollis, T. (2015). Chapter thirty-three: Activism, reflection, and Paulo Freire-an embodied pedagogy. Counterpoints, 500. In Paulo Freire: The global legacy (2015) (pp. 517-527), Peter Lang AG.

Rose, B. (2017). Moving from chasm to convergence: Benefits and barriers to academic activism for social justice and equity. A Journal of Educational Research and Practice, 27(1), 67-78. 